\title{
Design, synthesis, and biological evaluation of symmetrical azine derivatives as novel tyrosinase inhibitors
}

\author{
Somaye Karimian' ${ }^{1}$ Fatemeh Kazemi', Mahshid Attarroshan², Maryam Gholampour ${ }^{3}$, Shiva Hemmati,4,5, \\ Amirhossein Sakhteman ${ }^{1}$, Yasaman Behzadipour ${ }^{1}$, Maryam Kabiri ${ }^{1}$, Aida Iraji ${ }^{6,7^{*}}$ and Mehdi Khoshneviszadeh ${ }^{1,2^{*}}$
}

\begin{abstract}
A series of symmetrical azine derivatives containing different substituted benzyl moieties were designed, synthesized, and evaluated for their inhibitory activity against tyrosinase. The results showed that compounds $\mathbf{3 e}, \mathbf{3} \mathbf{f}, \mathbf{3} \mathbf{h}, \mathbf{3 i}, \mathbf{3} \mathbf{j}$, and 3k possess effective tyrosinase inhibition with $\mathrm{IC}_{50}$ values ranging from $7.30 \mu \mathrm{M}$ to $62.60 \mu \mathrm{M}$. Particularly, compounds $\mathbf{3 f}$ displayed around three-fold improvement in the potency $\left(\mathrm{IC}_{50}=7.30 \pm 1.15 \mu \mathrm{M}\right)$ compared to that of kojic acid $\left(I C_{50}=20.24 \pm 2.28 \mu \mathrm{M}\right)$ as the positive control. Kinetic study of compound $\mathbf{3} \mathbf{f}$ confirmed uncompetitive inhibitory activity towards tyrosinase indicating that it can bind to enzyme-substrate complex. Next, molecular docking analysis was performed to study the interactions and binding mode of the most potent compound $\mathbf{3} \mathbf{f}$ in the tyrosinase active site. Besides, the cytotoxicity of $\mathbf{3} \mathbf{f}$, as well as its potency to reduce the melanin content were also measured on invasive melanoma B16F10 cell line. Also, $3 f$ exhibited above $82 \%$ cell viability in the A375 cell line at $10 \mu \mathrm{M}$. Consequently, compounds $\mathbf{3} \mathbf{f}$ could be introduced as a potent tyrosinase inhibitor that might be a promising candidate in the cosmetics, medicine, and food industry.
\end{abstract}

Keywords: Melanin, Azine derivatives, Tyrosinase inhibitors, Molecular docking

\section{Introduction}

Melanin is known as a major pigment found in the eyes, hair, and skin of animals and humans which has protective roles against the harmful effects of ultraviolet (UV) irradiation, oxidative stress, DNA damage, and malignant transformation $[1,2]$. Despite the key features of melanin, excessive production, and hyperpigmentation of melanin cause dermatological disorders such as melasma, ephelides, chloasma, freckles, melanoderma, and senile lentigines [3]. The excess melanin synthesis can also

\footnotetext{
*Correspondence: iraji@sums.ac.ir; aida.iraji@gmail.com; m.khoshneviszadeh@gmail.com

${ }^{1}$ Department of Medicinal Chemistry, School of Pharmacy, Shiraz University of Medical Sciences, Shiraz, Iran

${ }^{6}$ Stem Cells Technology Research Center, Shiraz University of Medical Sciences, Shiraz, Iran

Full list of author information is available at the end of the article
}

induce inflammation such as eczema, irritant and allergic eczema contact dermatitis, which may be attributed to critical and emotionally distressing difficulty [4]. Moreover, there is some evidence about the correlation between neuromelanin and the pathogenesis of Parkinson's disease [5]. Also in the agricultural industry, overproduction of melanin in fruits and vegetables causes food browning and decline in product quality [6].

Tyrosinase (Polyphenol oxidase, a copper-containing enzyme, PPO, E.C.1.14.18.1) is a critical rate-limiting enzyme in the melanogenesis pathway. Tyrosinase plays a central role in the biosynthesis pathway of melanin pigment by catalyzing the hydroxylation and oxidation of monophenols to $o$-diphenols (monophenolase activity) and the oxidation of $o$-diphenols to $o$-quinones (diphenolase activity) [7]. To get rid of the mentioned undesirable problems, searching for novel and effective tyrosinase 
inhibitors is highly demanded. Although a large number of tyrosinase inhibitors have been discovered [8] such as chalcones [9], stilbenes [10-13], flavonol [14], flavone [15, 16], flavanone [17], flavanol [18], kojic acid [19-23], tropolone [8, 24-27], phthalimide [28], triazole [29] thiosemicarbazide [30] and quinazoline [31] derivatives (Fig. 1), only a few of them have been applied to the market due to their harmful and undesirable side effects, such as lack of safety, low efficacy and allergenic reactions [32, 33]. Consequently, it is necessary to search for new and potent tyrosinase inhibitors with fewer adverse effects.

Azines, N-N linked diamines are useful and stable compounds with interesting chemical attributes. Recently, azine-containing compounds gain lots of attention as important scaffold for drug designing owing to their modulating behavior towards bio-receptors [34, 35]. Azines also demonstrated antibacterial, antimalarial, antiviral, antitumor, and anti-inflammatory properties $[36,37]$.

As a result, in this study, novel series of azine derivatives were rationally designed, synthesized, and evaluated against the tyrosinase enzyme. Molecular docking analysis of the most potent derivative was also obtained to achieve a distinct insight into the binding mode and interactions of the compounds in the tyrosinase enzyme active site. Moreover, the kinetic, cytotoxic, as well as melanin content assays, were also performed.

\section{Results and discussion \\ Design approach}

Resveratrol (3,5,4'-trihydroxy-trans-stilbene) (A) is a natural antioxidant with numerous beneficial effects on human health such as neuroprotective, cardioprotective, anti-inflammatory, and anti-cancer effects which prompted the use of resveratrol as a therapeutic agent $[38,39]$. Resveratrol is also known as a powerful tyrosinase inhibitor with an $\mathrm{IC}_{50}$ value of $26.63 \mu \mathrm{M}$ with no marked toxicity (main concern at doses of $\geq 0.5 \mathrm{~g} /$ day for long-term use) [40].

Oozeki et al. reported resveratrol base structure as strong tyrosinase inhibitors with an $\mathrm{IC}_{50}$ value of $0.37 \mu \mathrm{M}$ for the most potent compound (compound B, Fig. 2). Their results showed that the symmetry bibenzyl skeleton could easily bind to the active site of the tyrosinase and improved the inhibitory potency [41]. Furthermore, incorporation of an azo group into the linker while keeping bi-aryl structure gave azo-resveratrol derivatives. Particularly, compound $\mathbf{C}$ showed $\mathrm{IC}_{50}=36.28 \pm 0.72 \mu \mathrm{M}$ in

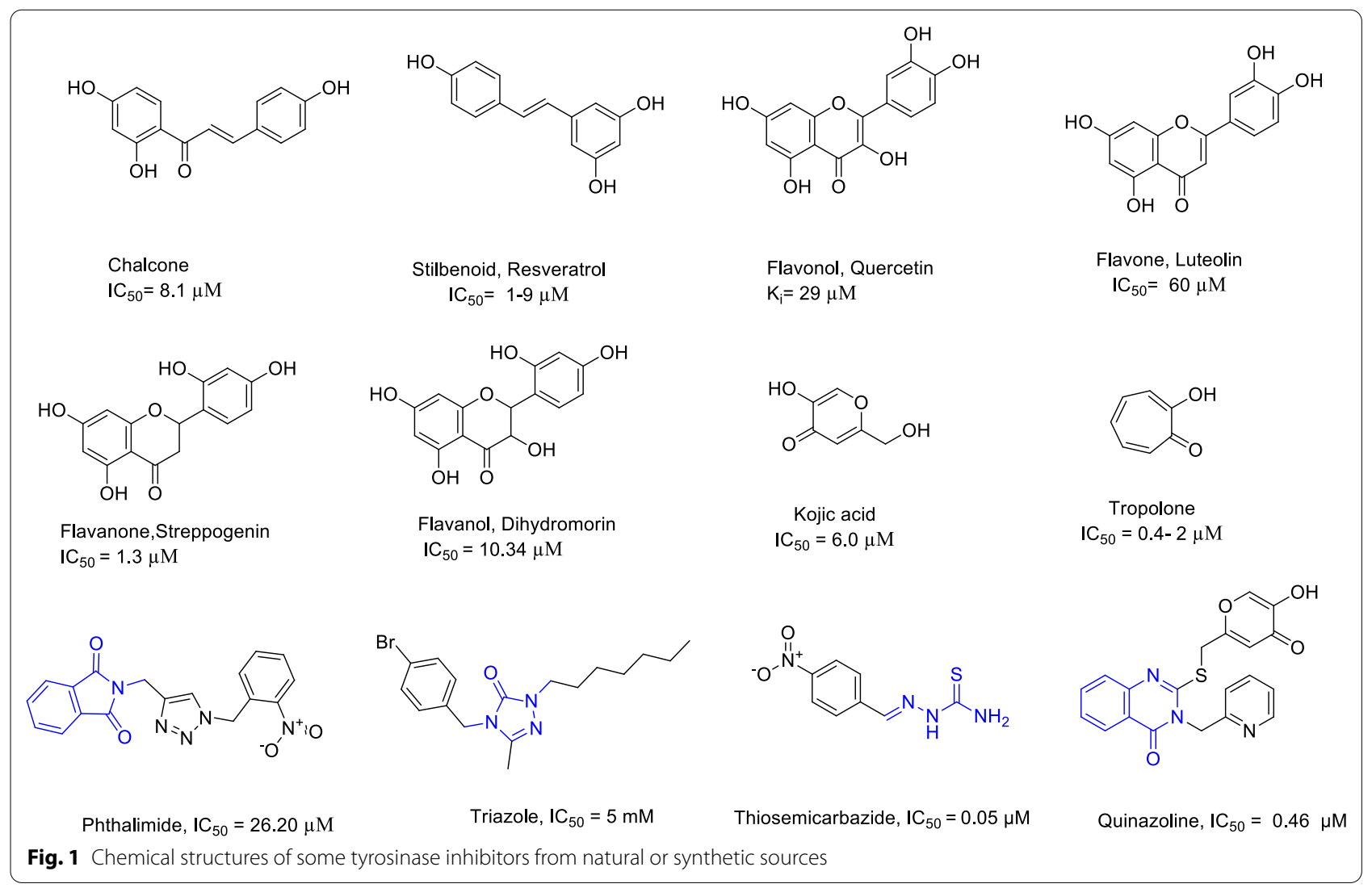


<smiles>Oc1ccc(/C=C/c2cc(O)cc(O)c2)cc1</smiles>

A: $\mathrm{IC}_{50}=57.05^{\mathrm{OH}}$

$\mathrm{HO}$<smiles>Oc1ccccc1/C=N/c1ccccc1O</smiles>

B: $\mathrm{IC}_{50}=417.71 \mathrm{M}$<smiles>COc1cc(/C=N/c2ccccc2)ccc1O</smiles>

C: $\mathrm{IC}_{50}=147.96$<smiles>CCOc1cc(C=NNC(=O)c2ccc(O)cc2)ccc1O</smiles>

D: $\mathrm{IC}_{50}=9.9 \mu \mathrm{M}$<smiles>CCOc1cc(/C=N/NC(=O)c2ccc(O)c(OC)c2)ccc1O</smiles>

E: $\mathrm{IC}_{50}=1.58 \mu \mathrm{M}$

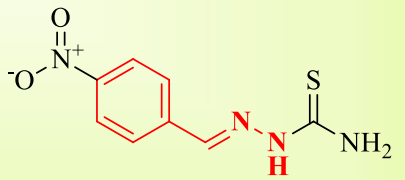

F: $\mathrm{IC}_{50}=0.05 \mu \mathrm{M}$

Fig. 2 Molecular hybridization and fragment-based approach for designing of bis-aryl hydrazine derivatives as tyrosinase inhibitors

a dose-dependent manner, comparable to that of resveratrol [42].

Recently, it has been reported that some hydrazinecontaining compounds, such as compounds D [43], E [44], and $\mathbf{F}$ [45], were effective tyrosinase inhibitors with an $\mathrm{IC}_{50}$ value of $9.9,1.58$, and $0.05 \mu \mathrm{M}$, respectively [46, 47]. Considering these structural features of all depicted compounds, most of them contain the same pharmacophore so that a linker with optimum length (two to four atoms) is connected to two aromatic rings (Ring $\mathrm{X}$-Linker-Ring Y).

As a result, molecular hybridization and fragmentbased drug design strategy were performed to develop a series of 1,2-bisaryl hydrazine derivatives as tyrosinase inhibitors. Various substituents were performed on benzylidene moieties to define beneficial structure-activity relationships (SARs).

\section{Chemistry}

A series of bis aryl hydrazine hybrids (3a-k) was synthesized according to the general synthetic route depicted in Scheme 1 . Commercially available aryl aldehydes (1) were reacted with hydrazine hydrate (2) in refluxing ethanol for $24 \mathrm{~h}$ to give the corresponding compounds $(3 \mathbf{a}-\mathbf{k})$. After cooling, the precipitate was filtered, washed with cold water, and recrystallized in methanol. The structures were fully characterized and confirmed by IR, ${ }^{1} \mathrm{H}-\mathrm{NMR}$, ${ }^{13} \mathrm{C}-\mathrm{NMR}, \mathrm{MS}$, and elemental analysis.

\section{Tyrosinase inhibitory activity}

The inhibitory effects of all synthesized derivatives (3ak) on tyrosinase are presented in terms of $\mathrm{IC}_{50}$ in Table 1 . Kojic acid was used as a positive control for comparative purposes. In general, six compounds $\mathbf{3 e}, \mathbf{3 f}, \mathbf{3 h}, \mathbf{3 i}, \mathbf{3} \mathbf{j}$, and 3k showed considerable inhibitory effects on tyrosinase with $\mathrm{IC}_{50}$ ranging from 7.3 to $62.6 \mu \mathrm{M}$.

The unsubstituted benzyl derivative (3a) had no significant inhibitory activity at the tested concentrations $\left(\mathrm{IC}_{50}>100 \mu \mathrm{M}\right)$.

To investigate the effect of the substituted moiety, different groups were introduced on the benzyl pendant. In the case of mono-substitution, it was found that the presence of one methoxy at different positions of benzyl ring did not show any improvement in the inhibitory activity (3b, $\mathrm{R}=$ ortho- $\mathrm{OCH}_{3}$ with $\mathrm{IC}_{50}>100 \mu \mathrm{M}$ and $\mathbf{3 c}$, $\mathrm{R}=$ para $-\mathrm{OCH}_{3}$ with $\mathrm{IC}_{50}>100 \mu \mathrm{M}$ ) compared to unsubstituted one. The isosteric replacement of methoxy at para position (3c), with a hydroxyl group in compound $3 \mathbf{j}$, increased the inhibitory effect against tyrosinase $\left(\mathrm{IC}_{50}=62.6 \pm 0.71 \mu \mathrm{M}\right)$.

Besides, compared to mono substitutions, multisubstitutions on benzyl ring significantly enhanced 


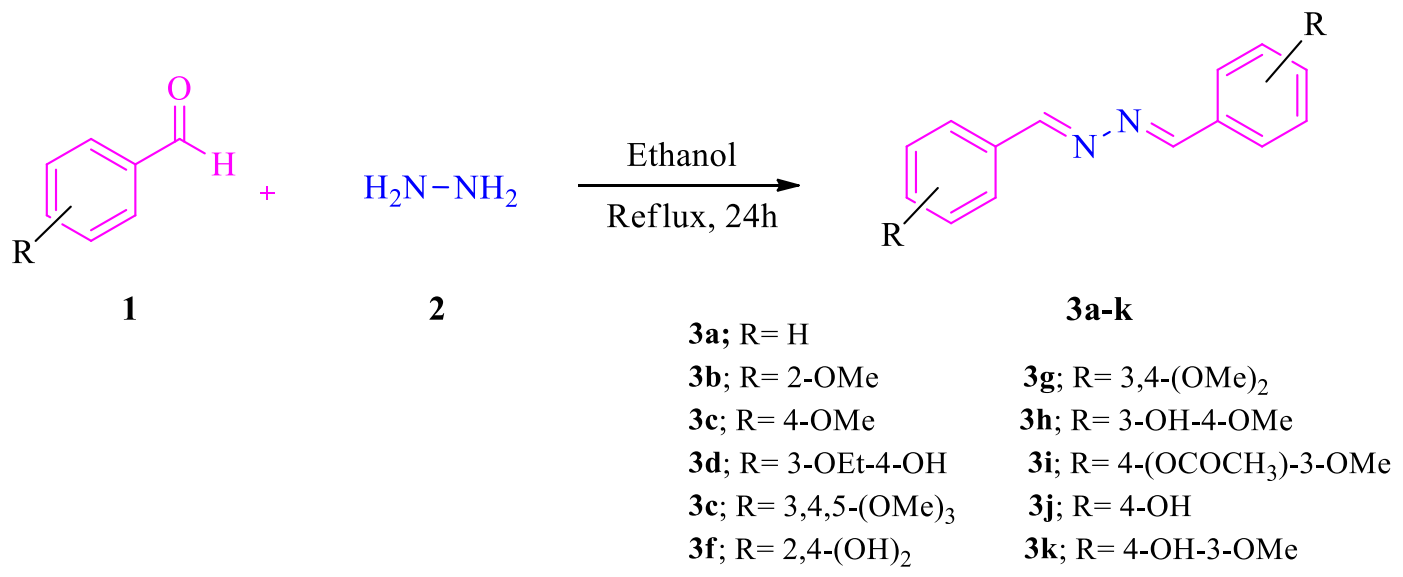

Scheme 1 The synthetic route for the synthesis of bis aryl hydrazine derivatives (3a-k)

Table 1 Tyrosinase inhibitory effects of synthesized compounds $\mathbf{3 a}-\mathbf{j}$ in comparison with kojic acid and Binding energy<smiles>[R]c1ccc(/C=N/N=C/c2ccc([R])cc2)cc1</smiles>

\begin{tabular}{|c|c|c|}
\hline \multicolumn{3}{|c|}{ Tyrosinase inhibitory activity ${ }^{a}$} \\
\hline Compounds & $\mathbf{R}$ & $I C_{50}(\mu \mathrm{M})^{\mathrm{b}}$ \\
\hline $3 a$ & $\mathrm{H}$ & $>100$ \\
\hline $3 b$ & 2-OMe & $>100$ \\
\hline $3 c$ & 4-OMe & $>100$ \\
\hline $3 d$ & 3-OEt-4-OH & $>100$ \\
\hline $3 e$ & $3,4,5-(\mathrm{OMe})_{3}$ & $20.10 \pm 0.01$ \\
\hline $3 f$ & $2,4-(\mathrm{OH})_{2}$ & $7.30 \pm 1.15$ \\
\hline $3 g$ & $3,4-(\mathrm{OMe})_{2}$ & $>100$ \\
\hline $3 h$ & 3-OH-4-OMe & $57.34 \pm 0.02$ \\
\hline $3 \mathbf{i}$ & 4-(OCOCH$\left.)_{3}\right)-3-\mathrm{OMe}$ & $28.11 \pm 0.52$ \\
\hline $3 \mathbf{j}$ & $4-\mathrm{OH}$ & $62.60 \pm 0.71$ \\
\hline $3 k$ & 4-OH-3-OMe & $12.90 \pm 0.18$ \\
\hline Kojic acid & - & $20.24 \pm 2.28$ \\
\hline
\end{tabular}

inhibitory potency as can be seen in compounds $\mathbf{3 e}, \mathbf{3 f}$, $\mathbf{3 h}, \mathbf{3 i}$, and 3k. The exception in this series came back to the compounds $3 d\left(\mathrm{R}=3-\mathrm{OEt}-4-\mathrm{OH}, \mathrm{IC}_{50}>100 \mu \mathrm{M}\right)$ and $3 \mathbf{g}\left(\mathrm{R}=3,4-(\mathrm{OMe})_{2}, \mathrm{IC}_{50}>100 \mu \mathrm{M}\right)$ which depicted weak anti-tyrosinase activity. Particularly, the most potent ligand identified in this study was compound $\mathbf{3 f}$ bearing 2,4-dihydroxy moiety with $\mathrm{IC}_{50}=7.30 \pm 1.15 \mu \mathrm{M}$, followed by $3 \mathbf{k}(\mathrm{R}=3-\mathrm{OMe}-4-\mathrm{OH})$ with an $\mathrm{IC}_{50}$ value of $12.90 \pm 0.18 \mu \mathrm{M}$. On the other hand, the substitution of a para hydroxyl group in compound $3 \mathbf{k}(\mathrm{R}=3-\mathrm{OMe}-$ 4-OH, $\left.\mathrm{IC}_{50}=12.9 \pm 0.18 \mu \mathrm{M}\right)$ with an acetoxy moiety resulted in $3 \mathbf{i}$ which showed a significant decrease in the inhibitory effect $\left(\mathrm{IC}_{50}=28.1 \mu \mathrm{M}\right)$. From the screening data, 3e containing 3,4,5-trimethoxy substituted groups at $\mathrm{R}$ known as the third potent compound in this series $\left(\mathrm{IC}_{50}=20.10 \pm 0.01 \mu \mathrm{M}\right)$ with approximately the same value of potency compared to that of the standard kojic acid with an $\mathrm{IC}_{50}$ value of $20.24 \pm 2.28 \mu \mathrm{M}$.

\section{Kinetic studies}

Kinetic studies were performed to examine the mechanism and type of inhibition by compound $\mathbf{3 f}$ as the most potent derivative against tyrosinase. The results are presented in Fig. 3. Lineweaver-Burk plots (plot of 1/V versus $1 /[S]$ ) for the inhibition of tyrosinase were obtained with several concentrations of $\mathbf{3 f}$ as the inhibitor and L-DOPA as the substrate. The analysis showed that $\mathrm{V}_{\max }$ and $K_{m}$ values decreased in the presence of increasing concentrations of compound 3f. With these results, it can presume that the type of inhibition for compound $\mathbf{3 f}$ is uncompetitive.

\section{Molecular docking study}

The molecular binding analysis was then performed to gain an understanding of the interactions and binding mode of $\mathbf{3 f}$ in the tyrosinase active site. The results are presented in Table 2. Tyrosinase has $\mathrm{H}_{2} \mathrm{~L}_{2}$ tetramer structure with two $\mathrm{H}$ subunits and two $\mathrm{L}$ subunits. The active site placed in the $\mathrm{H}$ subunit comprises binuclear copper ions so that the first copper ion demonstrated interactions with three histidine residues named His 61 , His 85 , 


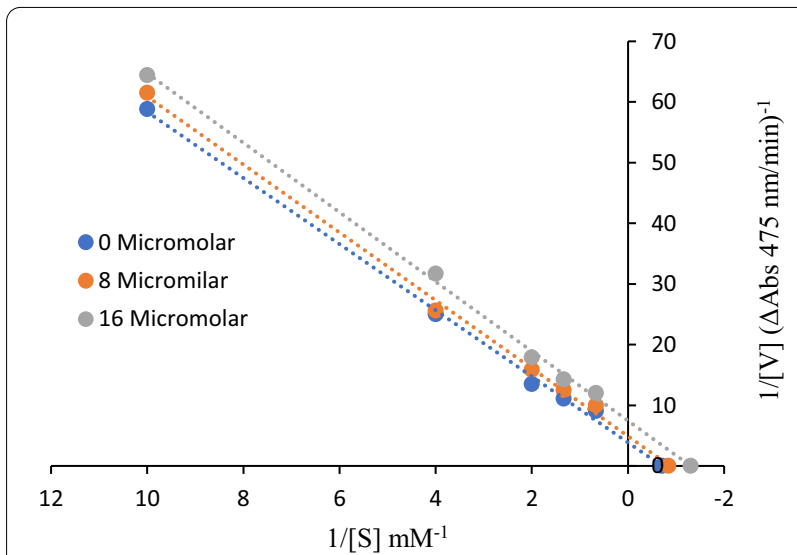

Fig. 3 Lineweaver-Burk plot of mushroom tyrosinase enzyme inhibition by different concentrations of $\mathbf{3} \mathbf{f}$ in the presence of L-DOPA as a substrate. The reciprocal tyrosinase inhibitory activity was plotted against the reciprocal substrate concentration (double reciprocal plot, $n=3) . K_{m}$ is the Michaelis-Menten constant and $V_{\max }$ is the maximum reaction velocity

Table 2 Molecular docking results of compound $\mathbf{3 f}$ with mushroom tyrosinase (PDB ID: 2Y9X)

\begin{tabular}{llll}
\hline Compound & Residues & Interaction type & Distance \\
\hline & His259 & Hydrogen bond & 3.07 \\
Val283 & Hydrogen bond & 2.77 \\
Val283 & Hydrophobic (Pi-Sigma) & 3.80 \\
& His296 & Hydrogen bond & 2.78 \\
Met280 & Hydrogen bond & 2.80 \\
3f & Gly281 & Hydrogen bond & 3.74 \\
& His263 & Electrostatic (Pi-Cation) & 3.88 \\
& Arg268 & Electrostatic (Pi-Cation) & 3.76 \\
& His263 & Hydrophobic (Pi-Pi) & 3.97 \\
& Phe264 & Hydrophobic (Pi-Pi) & 5.24 \\
& Ala286 & Hydrophobic (Pi-Alkyl) & 5.09 \\
\hline
\end{tabular}

and His95. The second copper ion coordinated by His 259, His 263, and His 296. Detailed and comprehensive studies confirmed that interactions with these critical residues can completely inactivate the monophenolase and diphenolase activity.

As shown in Fig. 4, compound 3f fitted well in the tyrosinase binding pocket by hydrogen bonding, electrostatic and hydrophobic interactions. The nitrogen atoms and the oxygen atoms of $\mathbf{3 f}$ formed five hydrogen bonds interacting with the Val 283, Gly 281, His 296, Met 280 , and His 259 residues at distances of $2.80 \AA$, $3.74 \AA$, $2.78 \AA, 2.80 \AA$, and $3.07 \AA$, respectively. Moreover, compound $3 \mathbf{f}$ was involved in electrostatic interactions with His263 and Arg268 as well as hydrophobic interactions with Phe264, Val283, His263, and Ala286. Docking results indicated that the substitution on the phenyl ring
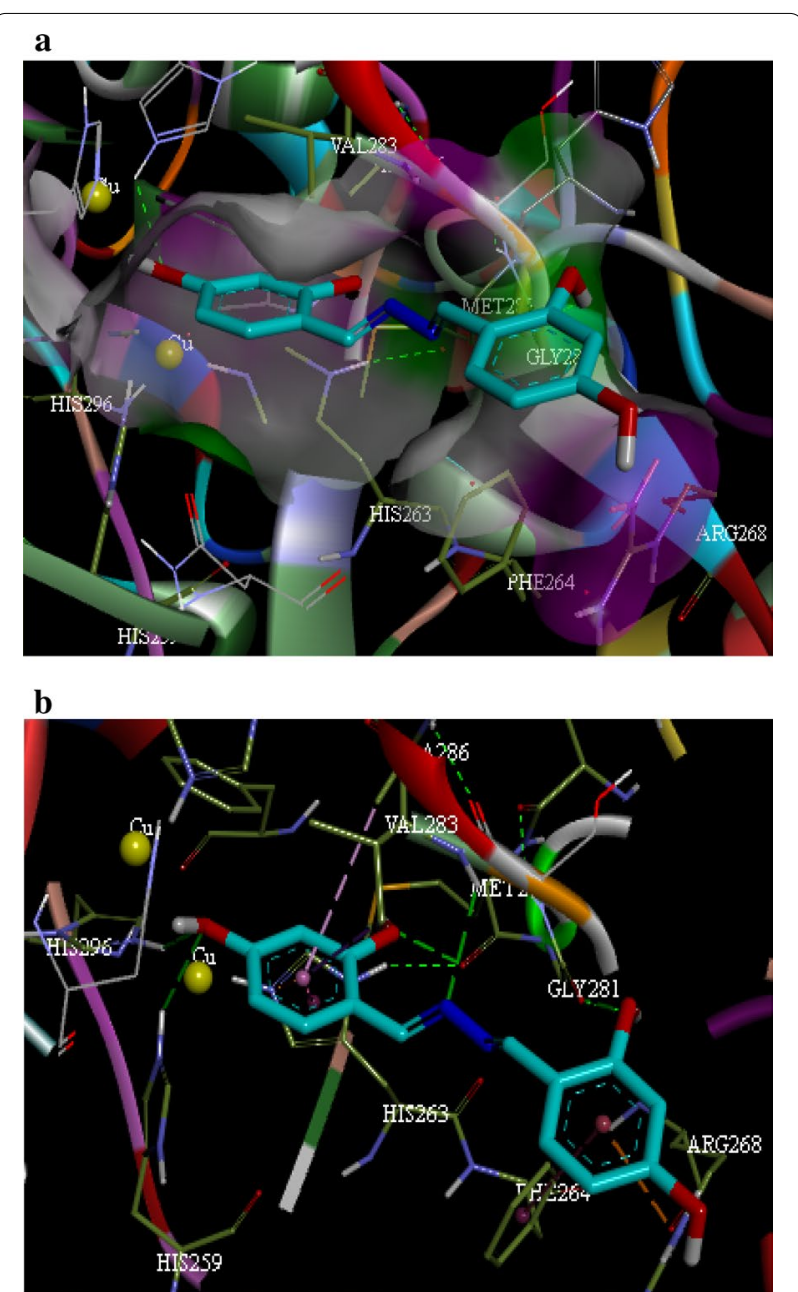

Fig. 4 The binding orientation (a) and interactions (b) of compound $\mathbf{3 f}$ into the tyrosinase enzyme. Ligand $\mathbf{3} \mathbf{f}$ is displayed as cyan sticks, while the core residues are shown as green sticks. Hydrogen bonding, electrostatic, Pi-Pi, and alkyl-Pi interactions are displayed as green, orange, pink and light pink, respectively

played an important role in forming drug-receptor interactions and binding orientation of the compound in the active site of tyrosinase by enhancing phenyl ring electron density.

\section{Cell viability on B16F10}

MTT assay was performed to determine the toxicity of 3f as the most potent tyrosinase inhibitor against invasive melanoma B16F10 cell line. According to the toxicity assay, 3f showed $60.15 \pm 9.82 \%( \pm \mathrm{SD})$ cell viability at $10 \mu \mathrm{M}$.

\section{Measuring cell viability of $A 375$ in response to $3 f$}

The A375 cell line is derived from a human skin melanoma carrying two mutant genes, B-RAF and CDKN2 
which are associated with melanoma of sun-damaged skin [48]. To determine the cytotoxicity of $\mathbf{3 f}$ in A375 melanoma cell lines, MTT studies were conducted. Results exhibited that the cell viability was significantly higher in A375 with 82.59 $\pm 5.85( \pm \mathrm{SD}) \%$ viability compared with the B16F10 cell line at $10 \mu \mathrm{M}$.

\section{Melanin content assay}

It is well documented that effective tyrosinase inhibitors may reduce the phenolase activities of the enzyme which in return downregulates the melanogenesis process $[49,50]$. In this regard, the potency of $3 \mathbf{f}$ to reduce the melanin content was evaluated on the B16F10 cell line. Kojic acid was used as the positive control. Data were expressed as mean $\pm \mathrm{SD}$ of at least three independent experiments. According to Fig. 5, 3f significantly reduced the melanin content in skin melanoma cells to $79.58 \%$ at $10 \mu \mathrm{M}$ in comparison with the control (P-value $<0.05$ ).

\section{Conclusion}

Following our expertise in the rational design of tyrosinase inhibitors; herein, we designed, synthesized, and evaluated different azine substituted derivatives against tyrosinase. The most active compound $\mathbf{3 f}$ bearing 2,4-dihydroxy on the benzyl ring $\left(\mathrm{IC}_{50}=7.30 \pm 1.15 \mu \mathrm{M}\right)$ showed 3 times better potency compared to that of kojic acid as the positive control. Moreover, it is worth mentioning that 3f showed an uncompetitive inhibition mode of action in the enzymatic assay. Molecular docking analysis demonstrated that the high potential of $3 \mathbf{f}$ would be due to the formation of strong interactions with the critical residues of the tyrosinase active site. In addition, cell assessments of $3 \mathbf{f}$ at $10 \mu \mathrm{M}$ against B16F10 and A375 cell lines exhibited around $60 \%$ and $82 \%$ viability, respectively. Importantly, compound 3f showed approximately similar potency to reduce the melanin content on B16F10 cell lines at $10 \mu \mathrm{M}$ compared to kojic acid as a positive

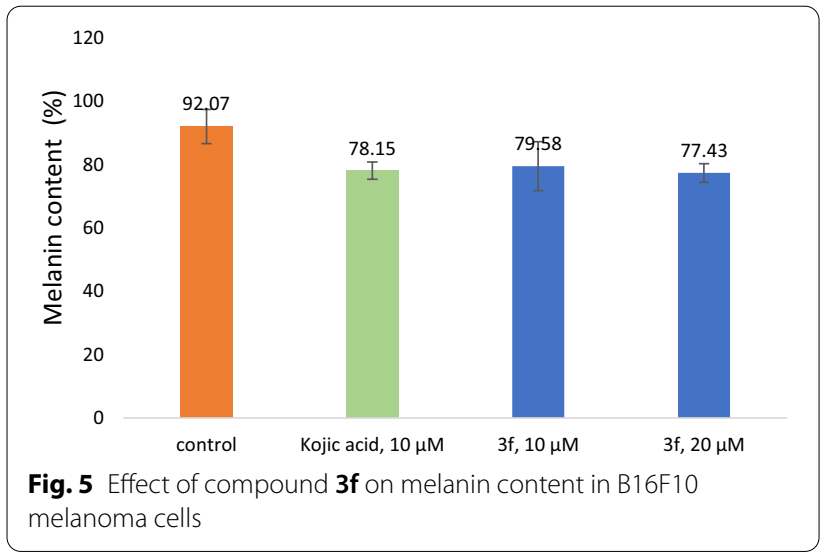

control. In general, it can be concluded that the synthesized compounds can serve as structural outlines and promising lead to design and expand potential tyrosinase inhibitors.

\section{Material and methods General}

All needed chemicals were purchased from Merck and Acros chemical companies. All reagents and solvents were dried before use according to standard methods. Mushroom tyrosinase (EC1.14.18.1), kojic acid, dimethyl sulfoxide (DMSO), and L-3,4-dihydroxyphenylalanine (L-DOPA) were purchased from Sigma Chemical Co. (St. Louis, MO, USA). IR spectra were obtained on an FT-IR Perkin-Elmer Precisely system spectrophotometer (potassium bromide disks). Melting points were determined on a Kofler hot stage apparatus and are uncorrected. ${ }^{1} \mathrm{H}$ NMR and ${ }^{13} \mathrm{C}$ NMR spectra were recorded in DMSO using a Bruker Avance DPX instrument $\left({ }^{1} \mathrm{H}\right.$ NMR $500 \mathrm{MHz},{ }^{13} \mathrm{C}$ NMR $\left.125 \mathrm{MHz}\right)$. Chemical shifts $(\delta)$ were reported in parts per million (ppm) downfield from TMS as an internal standard. All of the coupling constants $(J)$ are in hertz. The mass spectra were run on an Agilent 6410 apparatus. Merck silica gel 60 F254 plates were used for analytical thin-layer chromatography (TLC). Preparative thin-layer chromatography was done with prepared glass-backed plates $\left(20 * 20 \mathrm{~cm}^{2}\right)$ using silica gel (MerckKieselgel 60 HF254, Art. 7739).

\section{Synthesis}

The typical procedure for the synthesis of bis aryl hydrazide derivatives

A mixture of aryl aldehyde ( $1 \mathrm{mmol})$, and hydrazine hydrate $(0.5 \mathrm{mmol})$ were refluxed in ethanol for $24 \mathrm{~h}$. The reaction proceeding was monitored by TLC ( $n$-hexane/ethyl acetate, $20: 1 \mathrm{v} / \mathrm{v}$ ). After completion of the reaction, the mixture was cooled to room temperature, the precipitated solid was isolated by filtration, all products were recrystallized from hot ethanol. Physical and spectral data of bis aryl hydrazide derivatives are given below [51-53].

\section{1,2-di(Benzylidene)hydrazine (3a)}

Yellow solid; Isolated yield: 65\%; m.p: $88-93{ }^{\circ} \mathrm{C}$; I.R (KBr, $\left.\mathrm{cm}^{-1}\right)$ : 3067, 3050, 3025, 3000, 2949, 1624, 1574, 1491, 1446. ${ }^{1} \mathrm{H}$ NMR $\left(300 \mathrm{MHz}, \mathrm{DMSO}-d_{6}\right) \delta_{\mathrm{H}}(\mathrm{ppm}): 8.58(\mathrm{~s}$, 2H), 7.98-7.81 (m, 4H), 7.55-7.32 (m, 6H). ${ }^{13} \mathrm{C}$ NMR $\left(75 \mathrm{MHz}, \mathrm{DMSO}-d_{6}\right) \delta_{\mathrm{c}}(\mathrm{ppm}): 156.30,134.20,130.89$, 128.76, 128.31. Anal. Calcd. For $\mathrm{C}_{14} \mathrm{H}_{12} \mathrm{~N}_{2}$ : C: 80.74; $\mathrm{H}$ : 5.81; N: 13.45; Found. C: 80.99; H: 5.83; N: 13.48.

\section{1,2-bis(2-Methoxybenzylidene)hydrazine (3b)}

Commercially available with CAS number of 17745-812. Yellow solid; isolated yield: $64 \%$; m.p: $142-146{ }^{\circ} \mathrm{C}$; I.R 
(KBr) $\mathrm{U}_{\max }\left(\mathrm{cm}^{-1}\right): 3075,3005,2965,2946,2842,1616$, 1576, 1485, 1468, 1438, 1321, 1250. ${ }^{1} \mathrm{H}$ NMR $(300 \mathrm{MHz}$, DMSO- $\left.d_{6}\right) \delta_{\mathrm{H}}(\mathrm{ppm}): 8.94(\mathrm{~s}, 2 \mathrm{H}), 7.98(\mathrm{~d}, J=7.3 \mathrm{~Hz}, 2 \mathrm{H})$, $7.51(\mathrm{t}, J=7.5 \mathrm{~Hz}, 2 \mathrm{H}), 7.15(\mathrm{~d}, J=7.5 \mathrm{~Hz}, 2 \mathrm{H}), 7.05(\mathrm{t}$, $J=7.5 \mathrm{~Hz}, 2 \mathrm{H}), 3.89$ (s, 6H). ${ }^{13} \mathrm{C}$ NMR $(75 \mathrm{MHz}$, DMSO$\left.d_{6}\right) \delta_{\mathrm{c}}(\mathrm{ppm}): 56.27,112.49,121.19,122.08,127.00,133.50$, 157.01, 159.22. MS (m/z, \%): 77.3(41), 91.3(90), 119.3(65), 131.3(26), 150.3(35), 161.3(13), 237.3(92), 268.3(100). Anal. Calcd. For $\mathrm{C}_{16} \mathrm{H}_{16} \mathrm{~N}_{2} \mathrm{O}_{2}$ : C: 71.62; $\mathrm{H}: 6.01 ; \mathrm{N}: 10.44$; Found. C: $72.92 ; \mathrm{H}: 6.00 ; \mathrm{N}: 10.45$.

\section{1,2-bis(4-Methoxybenzylidene)hydrazine (3c)}

Commercially available with CAS number of 2299-732. Yellow solid; isolated yield: $58 \%$; m.p: $164-166{ }^{\circ} \mathrm{C}$; I.R $(\mathrm{KBr}) \mathrm{U}_{\max }\left(\mathrm{cm}^{-1}\right): 3092,3059,2982,2971,2931,2878$, 1631, 1600, 1474, 1439, 1400, 1377, 1357. ${ }^{1} \mathrm{H}$ NMR $\left(300 \mathrm{MHz}, \mathrm{DMSO}-d_{6}\right) \delta_{\mathrm{H}}(\mathrm{ppm}): 3.83(\mathrm{~s}, 6 \mathrm{H}), 7.06(\mathrm{~s}, 4 \mathrm{H})$, $7.82(\mathrm{~s}, 4 \mathrm{H}), 8.64(\mathrm{~s}, 2 \mathrm{H}) .{ }^{13} \mathrm{C}$ NMR $\left(75 \mathrm{MHz}, \mathrm{DMSO}-d_{6}\right)$ $\delta_{\mathrm{c}}(\mathrm{ppm}): 55.86,114.87,127.03,130.44,160.96,162.15$. MS (m/z, \%): 77.3(34), 91.3(18), 107.3(42), 121.3(24), 134.3(46), 148.3(26), 161.3(70), 240.4(16), 268.3( $\left.\mathrm{M}^{+}, 83\right)$. Anal. Calcd. For $\mathrm{C}_{16} \mathrm{H}_{16} \mathrm{~N}_{2} \mathrm{O}_{2}$ : C: 71.62; $\mathrm{H}: 6.01 ; \mathrm{N}: 10.44$; Found. C: 72.92; H: 6.00; N: 10.45.

\section{4,4'-(Hydrazine-1,2-diylidenebis(methaneylylidene)) bis(2-ethoxyphenol) (3d)}

White solid; isolated yield: 69\%; m.p: $210-218{ }^{\circ} \mathrm{C}$; I.R $(\mathrm{KBr}) \mathrm{U}_{\max }\left(\mathrm{cm}^{-1}\right): 3435,3292,3052,2987,2968,2927$, 2838, 1620, 1500, 1461, 1420, 1377, 1251. ${ }^{1} \mathrm{H}$ NMR $\left(300 \mathrm{MHz}, \mathrm{DMSO}-d_{6}\right) \delta_{\mathrm{H}}(\mathrm{ppm}): 1.37(\mathrm{t}, J=5.4 \mathrm{H}), 4.07$ $(\mathrm{q}, J=5.4 \mathrm{H}), 6.90(\mathrm{~d}, J=7.5 \mathrm{~Hz}, 2 \mathrm{H}), 7.26(\mathrm{~d}, J=7.5 \mathrm{~Hz}$, $2 \mathrm{H}), 7.44(\mathrm{~s}, 2 \mathrm{H}), 8.57(\mathrm{~s}, 2 \mathrm{H}), 9.63(\mathrm{~s}, 2 \mathrm{H}) .{ }^{13} \mathrm{C}$ NMR $\left(7.5 \mathrm{MHz}, \mathrm{DMSO}-d_{6}\right) \delta_{\mathrm{c}}(\mathrm{ppm}): 15.16,64.30,111.92$, $116.06,123.76,126.00,147.57,150.55,161.06 . \mathrm{MS}(\mathrm{m} / \mathrm{z}$, $\%):$ 163.3(19), 191.4(41), 272.4(39), 299.4(23), 328.3( $\mathrm{M}^{+}$, 100). Anal. Calcd. For $\mathrm{C}_{18} \mathrm{H}_{20} \mathrm{~N}_{2} \mathrm{O}_{4}$ : C: 65.84; H: 6.14; N: 8.53; Found. C: 66.62; H: 6.15; N: 8.52.

\section{1,2-bis(3,4,5-Trimethoxybenzylidene)hydrazine (3e) [51]}

Yellow solid; isolated yield: 75\%; m.p: $201-205{ }^{\circ} \mathrm{C}$; I.R $(\mathrm{KBr}) \mathrm{U}_{\max }\left(\mathrm{cm}^{-1}\right):$ 3083, 3063, 3012, 2989, 2955, 2936, 2840, 1623, 1505, 1457, 1434, 1457, 1375, 1150. ${ }^{1} \mathrm{H}$ NMR (300 MHz, DMSO- $\left.d_{6}\right) \delta_{\mathrm{H}}(\mathrm{ppm}): 3.74(\mathrm{~s}, 6 \mathrm{H}), 3.85$ (s, 12H), $7.22(\mathrm{~s}, 4 \mathrm{H}), 8.66(\mathrm{~s}, 2 \mathrm{H}) .{ }^{13} \mathrm{C} \mathrm{NMR}(75 \mathrm{MHz}$, DMSO- $\left.d_{6}\right) \delta_{\mathrm{c}}(\mathrm{ppm}): 56.39,60.63,106.03,129.73,140.65$, 153.63, 161.72. MS (m/z, \%): 221.4(25), 345.4(23), 388.4 $\left(\mathrm{M}^{+}, 100\right)$. Anal. Calcd. For $\mathrm{C}_{20} \mathrm{H}_{24} \mathrm{~N}_{2} \mathrm{O}_{6}$ : C: 61.85; $\mathrm{H}: 6.23$; N: 7.21; Found. C: 69.76; H: 6.24; N: 7.20.

\section{4,4'-(Hydrazine-1,2-diylidenebis(methaneylylidene)) bis(benzene-1,3-diol) (3f)}

Yellow solid; isolated yield: $92 \%$; m.p: $313{ }^{\circ} \mathrm{C}$; I.R (KBr) $\mathrm{U}_{\max }\left(\mathrm{cm}^{-1}\right):$ 3518, 3468, 3214, 3097, 3096, 2998, 2936,
2891, 1616, 1589, 1534, 1453, 1251, 1121. ${ }^{1} \mathrm{H}$ NMR $\left(300 \mathrm{MHz}, \mathrm{DMSO}-d_{6}\right) \delta_{\mathrm{H}}(\mathrm{ppm}): 6.35(\mathrm{~d}, J=2.4 \mathrm{~Hz}, 2 \mathrm{H})$, $6.41(\mathrm{dd}, J=8.4,2.4 \mathrm{~Hz}, 2 \mathrm{H}), 7.41(\mathrm{~d}, J=8.4 \mathrm{~Hz}, 2 \mathrm{H}), 8.77$ (s, 2H), 10.27 (s, 2H), 11.39 (s, 2H). ${ }^{13} \mathrm{C} \mathrm{NMR} \mathrm{(75} \mathrm{MHz,}$ DMSO- $\left.d_{6}\right) \delta_{\mathrm{c}}$ (ppm): 102.95, 108.69, 110.73, 133.46, 161.16, 162.27, 162.54. MS (m/z, \%): 137.3(79), 255.4(36), 272.2( $\left.\mathrm{M}^{+}, 100\right)$. Anal. Calcd. For $\mathrm{C}_{14} \mathrm{H}_{12} \mathrm{~N}_{2} \mathrm{O}_{4}$ : C: 61.76; $\mathrm{H}: 4.44 ; \mathrm{N}: 10.29$; Found. C: $60.88 ; \mathrm{H}: 4.45 ; \mathrm{N}: 10.28$.

\section{1,2-bis(3,4-Dimethoxybenzylidene)hydrazine (3g) [52]}

Commercially available with CAS number of 17745-867. Yellow solid; isolated yield: $94 \%$; m.p: $197-199{ }^{\circ} \mathrm{C}$; I.R $(\mathrm{KBr}) \mathrm{U}_{\max }\left(\mathrm{cm}^{-1}\right): 3079,3003,2962,2930,2840,1624$, 1580, 1542, 1465, 1443, 1345, 1259. ${ }^{1} \mathrm{H}$ NMR (300 MHz, DMSO- $\left.d_{6}\right) \delta_{\mathrm{H}}(\mathrm{ppm}): 3.83(\mathrm{~s}, 12 \mathrm{H}), 7.05(\mathrm{~s}, 2 \mathrm{H}), 7.36$ (s, 2H), 7.49 (s, 2H), 8.63 (s, 2H). ${ }^{13} \mathrm{C}$ NMR (75 MHz, DMSO- $\left.d_{6}\right) \delta_{\mathrm{c}}(\mathrm{ppm}): 55.86,56.09,109.52,111.95,123.97$, 127.16, 134.76, 149.46, 161.25. MS (m/z, \%): 79.2(23), 164.3(13), 191.3(52), 286.4(27), 313.4(9), 328.3( $\left.\mathrm{M}^{+}, 100\right)$. Anal. Calcd. For $\mathrm{C}_{18} \mathrm{H}_{20} \mathrm{~N}_{2} \mathrm{O}_{4}$ : C: 65.84; H: 6.14; N: 8.53; Found. C: 64.96; H: 6.15; N: 8.52.

\section{5,5'-(Hydrazine-1,2-diylidenebis(methaneylylidene)) bis(2-methoxyphenol)(3h) [53]}

Yellow solid; isolated yield: $73 \%$; m.p: $270-275{ }^{\circ} \mathrm{C}$; I.R (KBr) $\mathrm{U}_{\max }\left(\mathrm{cm}^{-1}\right): 3295,3074,3009,2941,2842,1619,1579$, 1508, 1461, 1439, 1360, 1273, 1027. ${ }^{1} \mathrm{H}$ NMR (300 MHz, DMSO- $\left.d_{6}\right) \delta_{\mathrm{H}}(\mathrm{ppm}): 3.83(\mathrm{~s}, 6 \mathrm{H}), 7.01(\mathrm{~d}, J=8.1 \mathrm{~Hz}, 2 \mathrm{H})$, $7.23(\mathrm{~d}, J=8.1 \mathrm{~Hz}, 2 \mathrm{H}), 7.38(\mathrm{~s}, 2 \mathrm{H}), 8.53$ (s, 2H), 9.36 (s, $2 \mathrm{H}) .{ }^{13} \mathrm{C}$ NMR (75 MHz, DMSO- $\left.d_{6}\right) \delta_{\mathrm{c}}(\mathrm{ppm}): 56.05$, $112.25,113.78,122.29,127.33,147.23,151.08,161.13 . \mathrm{MS}$ (m/z, \%): 150.3(12), 177.3(64), 273.3(32), 300.3(M+, 100). Anal. Calcd. For $\mathrm{C}_{16} \mathrm{H}_{16} \mathrm{~N}_{2} \mathrm{O}_{4}$ : C: 63.99; $\mathrm{H}: 5.37 ; \mathrm{N}$ : 9.33; Found. C: 63.79; H: 5.39; N: 9.38.

\section{(Hydrazine-1,2-diylidenebis(methaneylylidene)) bis(2-methoxy-4, 1-phenylene) diacetate (3i)}

Yellow solid; isolated yield: $53 \%$; m.p: $165-170{ }^{\circ} \mathrm{C}$; I.R (KBr) $\mathrm{U}_{\max }\left(\mathrm{cm}^{-1}\right): 3075,3010,2944,2887,2849,1765,1632,1599$, 1508, 1474, 1457, 1375, 1272, 1155, 1030, 1010. ${ }^{1} \mathrm{H}$ NMR (300 MHz, DMSO- $\left.d_{6}\right) \delta_{\mathrm{H}}(\mathrm{ppm}): 2.29(\mathrm{~s}, 6 \mathrm{H}), 3.86(\mathrm{~s}, 6 \mathrm{H})$, 7.25 (d, J=7.2 Hz, 2H), 7.47 (d, J=7.2 Hz, 2H), 7.65 (s, $2 \mathrm{H}), 8.73$ (s, 2H). ${ }^{13} \mathrm{C}$ NMR (75 MHz, DMSO- $\left.d_{6}\right) \delta_{\mathrm{c}}(\mathrm{ppm})$ : 20.86, 56.33, 111.54, 122.45, 123.89, 133.11, 142.32, 151.70, 161.36, 168.81. MS (m/z, \%): 43.3(57), 177.3(34), 258.4(12), 273.4(23), 300.4(100), 341.5(51), 384.3( $\left.\mathrm{M}^{+}, 79\right)$. Anal. Calcd. For $\mathrm{C}_{20} \mathrm{H}_{20} \mathrm{~N}_{2} \mathrm{O}_{6}$ : C: 62.49; H: 5.24; N: 7.29; Found. C: 62.47; $\mathrm{H}: 5.25$; N: 7.32 .

\section{4,4'-(Hydrazine-1,2-diylidenebis(methaneylylidene)) diphenol (3j)}

Yellow solid; isolated yield: 78\%; m.p: $204-208{ }^{\circ} \mathrm{C}$; I.R (KBr) $\mathrm{U}_{\max }\left(\mathrm{cm}^{-1}\right):$ 3367, 3069, 3012, 2988, 2955, 2839, 
1620, 1577, 1490, 1470, 1280, 1089. ${ }^{1} \mathrm{H}$ NMR $(300 \mathrm{MHz}$, DMSO- $\left.d_{6}\right) \delta_{\mathrm{H}}(\mathrm{ppm}): 6.87(\mathrm{~d}, J=8.4 \mathrm{~Hz}, 4 \mathrm{H}), 7.70(\mathrm{~d}$, $J=8.4 \mathrm{~Hz}, 4 \mathrm{H}), 8.56(\mathrm{~s}, 2 \mathrm{H}), 10.11(\mathrm{~s}, 2 \mathrm{H}) .{ }^{13} \mathrm{C}$ NMR (75 MHz, DMSO- $d_{6}$ ) $\delta_{\mathrm{c}}$ (ppm): 116.22, 125.57, 130.56, 160.75, 160.84. MS (m/z, \%): 65.3(68), 93.3(22), 120.3(40), 147.3(84), 212.3(27), 223.3(9), 240.3( $\left.\mathrm{M}^{+}, 100\right)$. Anal. Calcd. For $\mathrm{C}_{14} \mathrm{H}_{12} \mathrm{~N}_{2} \mathrm{O}_{2}$ : C: 69.99; $\mathrm{H}: 5.03 ; \mathrm{N}: 11.66$; Found. C: 69.76; H: 5.09; N: 11.69.

\section{4,4'-(Hydrazine-1,2-diylidenebis(methaneylylidene)) bis(2-methoxyphenol) (3k)}

Commercially available with CAS number of 1696-602, Yellow solid; isolated yield: $62 \%$; m.p: $169-174{ }^{\circ} \mathrm{C}$; I.R (KBr) $U_{\max }\left(\mathrm{cm}^{-1}\right)$ : 3481, 3084, 3003, 2958, 2937, 2921, 2856, 1625, 1602, 1509, 1453, 1427, 1239, 1032. ${ }^{1} \mathrm{H}$ NMR $\left(300 \mathrm{MHz}\right.$, DMSO- $\left.d_{6}\right) \delta_{\mathrm{H}}(\mathrm{ppm}): 3.84(\mathrm{~s}, 6 \mathrm{H})$, $6.89(\mathrm{~d}, J=8.4 \mathrm{~Hz}, 2 \mathrm{H}), 7.27(\mathrm{dd}, J=8.4,1.8 \mathrm{~Hz}, 2 \mathrm{H})$, 7.47 (d, $J=1.8 \mathrm{~Hz}, 2 \mathrm{H}), 8.58$ (s, $2 \mathrm{H}), 9.72(\mathrm{~s}, 2 \mathrm{H}) .{ }^{13} \mathrm{C}$ NMR $\left(75 \mathrm{MHz}\right.$, DMSO- $\left.d_{6}\right) \delta_{\mathrm{c}}(\mathrm{ppm}): 55.97,110.48$, $115.95,123.96,125.99,148.44,150.34,161.08 . \mathrm{MS}(\mathrm{m} / \mathrm{z}$, \%): 150.3(12), 177.3(54), 258.4(25), 272.5(18), 299.6(54), 300.3( $\left.\mathrm{M}^{+}, 100\right)$. Anal. Calcd. For $\mathrm{C}_{16} \mathrm{H}_{16} \mathrm{~N}_{2} \mathrm{O}_{4}$ : C: 63.99; H: 5.37; N: 9.33; Found. C: 63.79; H: 5.39; N: 9.38.

\section{Tyrosinase assay}

Mushroom tyrosinase (EC 1.14.18.1) (Sigma Chemical Co.) was assayed as explained previously with slight modifications applying L-DOPA as substrate [54]. In spectrophotometric experiments, enzyme activity was monitored by observing dopachrome formation at $475 \mathrm{~nm}$. The stock solutions of test compounds $3 \mathbf{a}-\mathbf{k}$ and kojic acid were first dissolved in DMSO at $40 \mathrm{mM}$ and then diluted with phosphate buffer $(\mathrm{pH}=6.8)$ to the required concentrations. First, $10 \mu \mathrm{L}$ of mushroom tyrosinase $\left(0.5 \mathrm{mg} \mathrm{mL}^{-1}\right)$ was mixed with $160 \mu \mathrm{L}$ of phosphate buffer $(50 \mathrm{mM}, \mathrm{pH}=6.8)$ and then $10 \mu \mathrm{L}$ of the test sample in 96-well microplates was added. After the mixture was pre-incubated at $28^{\circ} \mathrm{C}$ for $20 \mathrm{~min}, 20 \mu \mathrm{L}$ of L-DOPA solution $(0.5 \mathrm{mM})$ was added to the phosphate buffer and dopachrome formation was monitored at $475 \mathrm{~nm}$ for $10 \mathrm{~min}$. DMSO without test compounds was used as the control, and kojic acid was used as the positive control. Each assay was conducted as three separate replicates. The final concentration of DMSO in the test solution was less than $2.0 \%$. The percent inhibition ratio was calculated according to the following equation:

\section{Determination of the inhibition type}

A series of experiments were performed to determine the inhibition kinetics of $3 \mathbf{f}$. The inhibitor concentrations were: $0,8,16 \mu \mathrm{M}$. Substrate (L-DOPA) concentrations were $(0.1,0.25,0.5,0.75$ and $1.5 \mathrm{mM})$ in kinetic studies. Pre-incubation and measurement time was the same as discussed in the mushroom tyrosinase inhibition assay protocol. Maximum initial velocity was determined from the initial linear portion of absorbance up to $10 \mathrm{~min}$ after addition of L-DOPA with 1 min interval. The Michaelis constant $\left(\mathrm{K}_{\mathrm{m}}\right)$ and the maximal velocity $\left(\mathrm{V}_{\max }\right)$ of the tyrosinase activity were determined by the LineweaverBurk plot at various concentrations of L-DOPA as a substrate. The inhibition type of the enzyme was assayed by Lineweaver-Burk plots of the inverse of velocities $(1 / \mathrm{V})$ versus the inverse of substrate concentrations $1 /$ [S] $\mathrm{mM}^{-1}$.

\section{Molecular docking study}

Docking was done by AutoDock 4.2 (http://autodock. scripps.edu) and AutoDock Tools 1.5.4 (ADT) (http:// mgltools.scripps.edu/). X-ray crystal structure of agaricus bisporus tyrosinase containing tropolone in the active site (PDB ID: 2Y9X), was regained from protein data bank (http://www.rcsb.org). Before the docking method, the water molecules and the inherent ligand were eliminated from the protein. Hydrogens were attached and non-polar hydrogens were merged. Also, Gasteiger charges were calculated for protein 2Y9X. 3D structures of ligands were drawn and minimized under Molecular Mechanics $\mathrm{MM}^{+}$and then Semiempirical AM1 methods using HyperChem software (http://www.hyper.com/). The pdbqt formats of the ligands were prepared by adding Gasteiger charges and setting the degree of torsions. The active site which contains $\mathrm{Cu}^{2+}$ metal ions were chosen for docking and the grids' center was placed on the tropolone's binding site. The box dimensions were set to $40 \times 40 \times 40$ with $0.375 \AA$ grid spacing. To determine the docking parameter file, a rigid macromolecule was elected. The Lamarckian genetic search algorithm was used and the number of GA runs was determined at 100 . The other parameters were left at program default values. The validity of the docking procedure was tested using the co-crystallized inhibitor as ligand and the above-mentioned protocol. Finally, conforma-

$$
\text { Inhibition }(\%)=100 \times\left(\mathrm{Abs}_{\text {control }}-\mathrm{Abs}_{\text {compound }}\right) / \mathrm{Abs}_{\text {control }} \text {. }
$$

The inhibitory activity of the tested compounds was expressed as the concentration that inhibited $50 \%$ of the enzyme activity $\left(\mathrm{IC}_{50}\right)$. tions having the lowest assumed free energies of binding were studied to be analyzed [55]. 


\section{MTT assay for cell viability}

The cytotoxic activity of compound was evaluated in B16F10 cells using 3-(4,5-dimethylthiazol-2-yl)-2,5-diphenyltetrazolium bromide (MTT) assay. Cells were seeded in a 96-well plate $\left(5 \times 10^{3}\right.$ cells/well $)$ and incubated at $37^{\circ} \mathrm{C}$ with samples at different concentrations for $48 \mathrm{~h}$. Following the treatment, cells were incubated with MTT $\left(0.5 \mathrm{mg} \mathrm{mL}^{-1}\right)$ at $37^{\circ} \mathrm{C}$ for $3 \mathrm{~h}$. The MTT-containing medium was then removed, and $100 \mu \mathrm{L}$ of DMSO was added to each well, mixed thoroughly with a $10 \mathrm{~min}$ shake to dissolve formazan crystals. The absorbance of each well was measured at $540 \mathrm{~nm}$.

\section{Determination of melanin content}

B16F10 cells were seeded in six-well plates $\left(1.0 \times 10^{5}\right.$ cells/well $)$. After $24 \mathrm{~h}$, the medium was substituted by a fresh one and treated with $\mathbf{3 f}$, and incubated for $48 \mathrm{~h}$. Then, cells were treated with $100 \mathrm{nM} \alpha-\mathrm{MSH}$. Kojic acid was used as positive control and for comparing the inhibitory strength of the compound. After incubation cells were washed twice with PBS and harvested using $0.25 \mathrm{M}$ trypsin, then dissolved in $300 \mu \mathrm{L}$ of $1 \mathrm{~N}$ $\mathrm{NaOH} / 10 \%$ DMSO buffer and boiled for $2 \mathrm{~h}$ at $80{ }^{\circ} \mathrm{C}$ to solubilize the melanin. The absorbance of the supernatant was measured at $470 \mathrm{~nm}$ in a microplate reader. The obtained results were normalized using total protein content.

\section{Acknowledgements}

Not applicable.

\section{Authors' contributions}

SK synthesized compounds as well as prepare the manuscript. FK synthesized compounds. MA performed the biological assay. MG performed the biological assay. SH supervised the biological tests. AS contributed to the design and characterization of compounds. YB performed the biological assay. MKabiri performed the biological assay. Al performed docking study and contributed to the preparation of the manuscript. MKhoshneviszadeh supervised all phases of the study. All authors read and approved the final manuscript.

\section{Funding}

The authors wish to thank the support of the Vice-Chancellor for Research of Shiraz University of Medical Sciences (Grant Number: 97-01-05-18440). This agency was not involved in the design of the study and collection, analysis, and interpretation of data as well as in writing the manuscript. This study was part of the Pharm.D thesis of Fatemeh Kazemi.

\section{Availability of data and materials}

The datasets used and analyzed during the current study are available from the corresponding author on reasonable request.

\section{Declarations}

Ethics approval and consent to participate Not applicable.

\section{Consent for publication}

Not applicable.

\section{Competing interests}

The authors declare that they have no competing interests.

\section{Author details}

'Department of Medicinal Chemistry, School of Pharmacy, Shiraz University of Medical Sciences, Shiraz, Iran. ${ }^{2}$ Medicinal and Natural Products Chemistry Research Center, Shiraz University of Medical Sciences, Shiraz, Iran. ${ }^{3}$ Pharmaceutical Sciences Research Center, Shiraz University of Medical Sciences, Shiraz, Iran. ${ }^{4}$ Department of Pharmaceutical Biotechnology, School of Pharmacy, Shiraz University of Medical Sciences, Shiraz, Iran. ${ }^{5}$ Biotechnology Research Center, Shiraz University of Medical Sciences, Shiraz, Iran. ${ }^{6}$ Stem Cells Technology Research Center, Shiraz University of Medical Sciences, Shiraz, Iran. ${ }^{7}$ Central Research Laboratory, Shiraz University of Medical Sciences, Shiraz, Iran.

Received: 2 June 2021 Accepted: 15 September 2021

Published online: 29 September 2021

\section{References}

1. Zhu Y-J, Qiu L, Zhou J-J, Guo H-Y, Hu Y-H, Li Z-C, Wang Q, Chen Q-X, Liu B. Inhibitory effects of hinokitiol on tyrosinase activity and melanin biosynthesis and its antimicrobial activities. J Enzyme Inhib Med Chem. 2010;25(6):798-803.

2. Brenner $\mathrm{M}$, Hearing VJ. The protective role of melanin against UV damage in human skin. Photochem Photobiol. 2008;84(3):539-49.

3. Lerner AB, Fitzpatrick TB. Treatment of melanin hyperpigmentation. J Am Med Assoc. 1953;152(7):577-82.

4. Kim YJ, Kang KS, Yokozawa T. The anti-melanogenic effect of pycnogenol by its anti-oxidative actions. Food Chem Toxicol. 2008;46(7):2466-71.

5. Bose A, Petsko GA, Eliezer D. Parkinson's disease and melanoma: cooccurrence and mechanisms. J Parkinsons Dis. 2018;8(3):385-98.

6. Taranto F, Pasqualone A, Mangini G, Tripodi P, Miazzi M, Pavan S, Montemurro C. Polyphenol oxidases in crops: biochemical, physiological and genetic aspects. Int J Mol Sci. 2017;18(2):377.

7. Seo S-Y, Sharma VK, Sharma N. Mushroom tyrosinase: recent prospects. J Agric Food Chem. 2003;51(10):2837-53.

8. Roulier B, Pérès B, Haudecoeur R. Advances in the design of genuine human tyrosinase inhibitors for targeting melanogenesis and related pigmentations. J Med Chem. 2020;63(22):13428-43.

9. Nerya O, Musa R, Khatib S, Tamir S, Vaya J. Chalcones as potent tyrosinase inhibitors: the effect of hydroxyl positions and numbers. Phytochemistry. 2004;65(10):1389-95.

10. Aggarwal BB, Bhardwaj A, Aggarwal RS, Seeram NP, Shishodia S, Takada Y. Role of resveratrol in prevention and therapy of cancer: preclinical and clinical studies. Anticancer Res. 2004;24:2783-840.

11. Shin NH, Ryu SY, Choi EJ, Kang SH, Chang IM, Min KR, Kim Y. Oxy-resveratrol as the potent inhibitor on dopa oxidase activity of mushroomtyrosinase. Biochem Biophys Res Commun. 1998;243:801-3.

12. Shimizu K, Kondo R, Sakai K, Lee SH, Sato H. The inhibitory componentsfrom Artocarpus incisus on melanin biosynthesis. Planta Med. 1998;64:408-12.

13. Likhitwitayawuid K, Sritularak B. A new dimeric stilbene with tyrosinaseinhibitiory activity from Artocarpus gomezianus. J Nat Prod. 2001;64(11):1457-9.

14. Xie LP, Chen QX, Huang H, Wang HZ, Zhang RQ. Inhibitory effects of some flavonoids on the activity of mushroom tyrosinase. Biochem Biokhimiia. 2003;68(4):487-91.

15. Kubo I, Kinst-Hori I. Flavonols from saffron flower: tyrosinase inhibitory activity and inhibition mechanism. J Agric Food Chem. 1999:47(10):4121-5.

16. Kwak J, Seok J, Suh HJ, Choi YH, Hong S, Kim D, Boo Y. Antimelanogenic effects of luteolin 7-sulfate isolated from Phyllospadix iwatensis Makino. $\mathrm{Br}$ J Dermatol. 2016;175(3):501-11.

17. Jeong SH, Ryu YB, Curtis-Long MJ, Ryu HW, Baek YS, Kang JE, Lee WS, Park $\mathrm{KH}$. Tyrosinase inhibitory polyphenols from roots of Morus Ihou. J Agric Food Chem. 2009;57(4):1195-203.

18. Zheng ZP, Cheng KW, To JT, Li H, Wang M. Isolation of tyrosinase inhibitors from Artocarpus heterophyllus and use of its extract as antibrowning agent. Mol Nutr Food Res. 2008;52(12):1530-8.

19. Burdock GA, Soni MG, Carabin IG. Evaluation of health aspects of kojic acid in food. Regul Toxicol Pharmacol. 2001;33(1):80-101.

20. Bentley R. From miso, sake and shoyu to cosmetics: a century of science forkojic acid. Nat Prod Rep. 2006;23:1046-62. 
21. Lajis AFB, Hamid M, Ariff AB. Depigmenting effect of kojic acid esters inhyperpigmented B16F1 melanoma cells. J Biomed Biotechnol. 2012. https://doi.org/10.1155/2012/952452.

22. Molenda JJ, Basinger MA, Hanusa TP, Jones MM. Synthesis and iron(III) binding properties of 3-hydroxypyrid-4-ones derived from kojic acid. J Inorg Biochem. 1994;55(2):131-46.

23. Kim H, Choi J, Cho JK, Kim SY, Lee Y-S. Solid-phase synthesis of kojic acidtripeptides and their tyrosinase inhibitory activity, storage stability, and toxicity. Bioorg Med Chem Lett. 2004;14(11):2843-6.

24. Ismaya WT, Rozeboom HJ, Weijn A, Mes JJ, Fusetti F, Wichers HJ, Dijkstra BW. Crystal structure of Agaricus bisporus mushroom tyrosinase: identity of the tetramer subunits and interaction with tropolone. Biochemistry. 2011;50:5477-86.

25. Flurkey A, Cooksey J, Reddy A, Spoonmore K, Rescigno A, Inlow J, Flurkey WH. Enzyme, protein, carbohydrate, and phenolic contaminants in commercial tyrosinase preparations: potential problems affecting tyrosinase activity and inhibition studies. J Agric Food Chem. 2008;56(12):4760-8.

26. Kahn $\mathrm{V}$, Andrawis A. Inhibition of mushroom tyrosinase by tropolone. Phytochemistry. 1985;24(5):905-8.

27. Neeley E, Fritch G, Fuller A, Wolfe J, Wright J, Flurkey W. Variations in IC50 values with purity of mushroom tyrosinase. Int J Mol Sci. 2009;10(9):3811-23.

28. Tehrani MB, Emani P, Rezaei Z, Khoshneviszadeh M, Ebrahimi M, Edraki N, Mahdavi M, Larijani B, Ranjbar S, Foroumadi A, et al. Phthalimide-1,2,3 triazole hybrid compounds as tyrosinase inhibitors; synthesis, biological evaluation and molecular docking analysis. J Mol Struct. 2019;1176:86-93.

29. Akın \$̧, Demir EA, Colak A, Kolcuoglu Y, Yildirim N, Bekircan O. Synthesis, biological activities and molecular docking studies of some novel 2,4,5-trisubstituted-1,2,4-triazole-3-one derivatives as potent tyrosinase inhibitors. J Mol Struct. 2019;1175:280-6.

30. Hosseinpoor H, Iraji A, Edraki N, Pirhadi S, Attarroshan M, Khoshneviszadeh $M$, Khoshneviszadeh M. A series of benzylidenes linked to hydrazine1-carbothioamide as tyrosinase inhibitors: synthesis, biological evaluation and structure-activity relationship. Chem Biodivers. 2020;17(8):e2000285.

31. Sepehri N, Iraji A, Yavari A, Asgari MS, Zamani S, Hosseini S, Bahadorikhalili S, Pirhadi S, Larijani B, Khoshneviszadeh M, et al. The natural-based optimization of kojic acid conjugated to different thio-quinazolinones as potential anti-melanogenesis agents with tyrosinase inhibitory activity. Bioorg Med Chem. 2021;36:116044.

32. Chiari ME, Vera DMA, Palacios SM, Carpinella MC. Tyrosinase inhibitory activity of a 6-isoprenoid-substituted flavanone isolated from Dalea elegans. Bioorg Med Chem. 2011;19(11):3474-82.

33. Karioti A, Protopappa A, Megoulas N, Skaltsa H. Identification of tyrosinase inhibitors from Marrubium velutinum and Marrubium cylleneum. Bioorg Med Chem. 2007;15(7):2708-14.

34. Kurteva VB, Simeonov SP, Stoilova-Disheva M. Symmetrical acyclic aryl aldazines with antibacterial and antifungal activity. Pharmacol Pharm. 2011;2(01):1.

35. Picón-Ferrer I, Hueso-Ureña F, Illán-Cabeza NA, Jiménez-Pulido SB, Martínez-Martos JM, Ramírez-Expósito MJ, Moreno-Carretero MN. Chlorofac-tricarbonylrhenium (I) complexes of asymmetric azines derived from 6-acetyl-1, 3, 7-trimethylpteridine-2, 4 (1H, 3H)-dione with hydrazine and aromatic aldehydes: preparation, structural characterization and biological activity against several human tumor cell lines. J Inorg Biochem. 2009;103(1):94-100.

36. Jayabharathi J, Thanikachalam V, Thangamani A, Padmavathy M. Synthesis, AM 1 calculation, and biological studies of thiopyran-4-one and their azine derivatives. Med Chem Res. 2007;16(6):266-79.

37. Easmon J, Pürstinger $G$, Heinisch $G$, Roth $T$, Fiebig HH, Holzer W, Jäger W, Jenny M, Hofmann J. Synthesis, cytotoxicity, and antitumor activity of copper (II) and iron (II) complexes of $4 \mathrm{~N}$-azabicyclo [3.2.2] nonane thiosemicarbazones derived from acyl diazines. J Med Chem. 2001;44(13):2164-71.

38. Berman AY, Motechin RA, Wiesenfeld MY, Holz MK. The therapeutic potential of resveratrol: a review of clinical trials. NPJ Precis Oncol. 2017:1(1):1-9.

39. Singh AP, Singh R, Verma SS, Rai V, Kaschula CH, Maiti P, Gupta SC. Health benefits of resveratrol: evidence from clinical studies. Med Res Rev. 2019;39(5):1851-91.
40. Cottart C-H, Nivet-Antoine V, Laguillier-Morizot C, Beaudeux J-L. Resveratrol bioavailability and toxicity in humans. Mol Nutr Food Res. 2010;54(1):7-16.

41. Oozeki H, Tajima R, Nihei K-I. Molecular design of potent tyrosinase inhibitors having the bibenzyl skeleton. Bioorg Med Chem Lett. 2008;18(19):5252-4.

42. Song YM, Ha YM, Kim J-A, Chung KW, Uehara Y, Lee KJ, Chun P, Byun Y, Chung HY, Moon HR. Synthesis of novel azo-resveratrol, azo-oxyresveratrol and their derivatives as potent tyrosinase inhibitors. Bioorg Med Chem Lett. 2012;22(24):7451-5.

43. Iraji A, Khoshneviszadeh M, Bakhshizadeh P, Edraki N, Khoshneviszadeh M. Structure-based design, synthesis, biological evaluation and molecular docking study of 4-hydroxy- $N^{\prime}$-methylenebenzohydrazide derivatives acting as tyrosinase inhibitors with potentiate anti-melanogenesis activities. Med Chem. 2020;16(7):892-902.

44. Iraji A, Adelpour T, Edraki N, Khoshneviszadeh M, Miri R, Khoshneviszadeh M. Synthesis, biological evaluation and molecular docking analysis of vaniline-benzylidenehydrazine hybrids as potent tyrosinase inhibitors. BMC Chem. 2020;14:1-11

45. Hosseinpoor H, Iraji A, Edraki N, Pirhadi S, Attarroshan M, Khoshneviszadeh $M$, Khoshneviszadeh M. A series of benzylidene linked to hydrazinecarbothioamide as tyrosinase inhibitors synthesis, biological evaluation and structure-activity relationship. Chem Biodivers. 2020;17(8):e2000285.

46. Yi W, Cao R-H, Chen Z-Y, Yu L, Ma L, Song H-C. Design, synthesis and biological evaluation of hydroxy-or methoxy-substituted phenylmethylenethiosemicarbazones as tyrosinase inhibitors. Chem Pharm Bull. 2009;57(11):1273-7.

47. Li Q, Yang H, Mo J, Chen Y, Wu Y, Kang C, Sun Y, Sun H. Identification by shape-based virtual screening and evaluation of new tyrosinase inhibitors. PeerJ. 2018;6:e4206.

48. Avram S, Coricovac D-E, Pavel IZ, Pinzaru I, Ghiulai R, Baderca F, Soica C, Muntean D, Branisteanu DE, Spandidos DA, et al. Standardization of A375 human melanoma models on chicken embryo chorioallantoic membrane and Balb/c nude mice. Oncol Rep. 2017;38(1):89-99.

49. Chang T-S. Natural melanogenesis inhibitors acting through the downregulation of tyrosinase activity. Materials. 2012;5(9):1661-85.

50. Pillaiyar T, Manickam M, Jung S-H. Downregulation of melanogenesis: drug discovery and therapeutic options. Drug Discov Today. 2017;22(2):282-98.

51. Hamid MHSA, Ali MA, Mirza AH, Len GA, Butcher RJ. (1E,2E)-1,2-Bis(2,3,4trimeth-oxy-benzyl-idene)hydrazine. Acta Crystallogr Sect E Struct Rep Online. 2010;66(Pt 10):o2557-o2557.

52. Parveen M, Azaz S, Malla AM, Ahmad F, Pereira da Silva PS, Ramos Silva M. Solvent-free, [Et3NH] [HSO4] catalyzed facile synthesis of hydrazone derivatives. New J Chem. 2015;39(1):469-81.

53. Shahzad D, Saeed A. Novel C-2 symmetric molecules as a-glucosidase and a-amylase inhibitors: design, synthesis, kinetic evaluation, molecular docking and pharmacokinetics. Molecules. 2019;24(8):1511.

54. Karimian S, Ranjbar S, Dadfar M, Khoshneviszadeh M, Gholampour M, Sakhteman A, Khoshneviszadeh M. 4 H-benzochromene derivatives as novel tyrosinase inhibitors and radical scavengers: synthesis, biological evaluation, and molecular docking analysis. Mol Divers. 2020. https://doi. org/10.1007/s11030-020-10123-0.

55. Iraji A, Panahi Z, Edraki N, Khoshneviszadeh M, Khoshneviszadeh M. Design, synthesis, in vitro and in silico studies of novel Schiff base derivatives of 2-hydroxy-4-methoxybenzamide as tyrosinase inhibitors. Drug Dev Res. 2021;82(4):533-42.

\section{Publisher's Note}

Springer Nature remains neutral with regard to jurisdictional claims in published maps and institutional affiliations. 